\title{
Vertical structure of MJO-related subtropical ozone variations from MLS, TES, and SHADOZ data
}

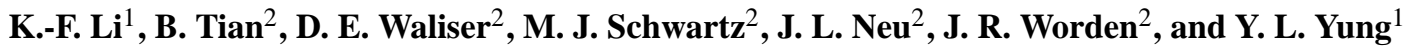 \\ ${ }^{1}$ Division of Geological and Planetary Sciences, California Institute of Technology, Pasadena, CA, USA \\ ${ }^{2}$ Jet Propulsion Laboratory, California Institute of Technology, Pasadena, CA, USA \\ Correspondence to: K.-F. Li (kfl@gps.caltech.edu)
}

Received: 5 August 2011 - Published in Atmos. Chem. Phys. Discuss.: 31 August 2011

Revised: 21 December 2011 - Accepted: 21 December 2011 - Published: 6 January 2012

\begin{abstract}
Tian et al. (2007) found that the MJO-related total column ozone $\left(\mathrm{O}_{3}\right)$ anomalies of $10 \mathrm{DU}$ (peak-to-trough) are mainly evident over the subtropics and dynamically driven by the vertical movement of the subtropical tropopause layer. It was then hypothesized that the subtropical total column $\mathrm{O}_{3}$ anomalies are primarily associated with the $\mathrm{O}_{3}$ variability in the stratosphere rather the troposphere. In this paper, we investigate the vertical structure of MJO-related subtropical $\mathrm{O}_{3}$ variations using the vertical $\mathrm{O}_{3}$ profiles from the Aura Microwave Limb Sounder (MLS) and Tropospheric Emission Spectrometer (TES), as well as in-situ measurements by the Southern Hemisphere Additional Ozonesondes (SHADOZ) project. Our analysis indicates that the subtropical $\mathrm{O}_{3}$ anomalies maximize approximately in the lower stratosphere $(60-100 \mathrm{hPa})$. Furthermore, the spatialtemporal patterns of the subtropical $\mathrm{O}_{3}$ anomalies in the lower stratosphere are very similar to that of the total column. In particular, they are both dynamically driven by the vertical movement of subtropical tropopause. The subtropical partial $\mathrm{O}_{3}$ column anomalies between $30-200 \mathrm{hPa}$ accounts for more than $50 \%$ of the total $\mathrm{O}_{3}$ column anomalies. TES measurements show that at most $27 \%$ of the total $\mathrm{O}_{3}$ column anomalies are contributed by the tropospheric components. This indicates that the subtropical total column $\mathrm{O}_{3}$ anomalies are mostly from the $\mathrm{O}_{3}$ anomalies in the lower stratosphere, which supports the hypothesis of Tian et al. (2007). The strong connection between the intraseasonal subtropical stratospheric $\mathrm{O}_{3}$ variations and the MJO implies that the stratospheric $\mathrm{O}_{3}$ variations may be predictable with similar lead times over the subtropics. Future work could involve a similar study or an $\mathrm{O}_{3}$ budget analysis using a sophisticated chemical transport model in the near-equatorial regions where the observed $\mathrm{MJO}$ signals of total column $\mathrm{O}_{3}$ are weak.
\end{abstract}

\section{Introduction}

The Madden-Julian oscillation (MJO), aka intraseasonal oscillation (Madden and Julian, 1971, 1972), is the dominant form of intraseasonal variability in the tropical atmosphere. It is characterized by slow $\left(\sim 5 \mathrm{~m} \mathrm{~s}^{-1}\right)$ eastward-propagating, large-scale oscillations in tropical deep convection and baroclinic winds, especially over the warmest waters in the equatorial Indian Ocean and western Pacific during boreal winter (November-April) when the Indo-Pacific Warm Pool is centered near the equator (Lau and Waliser, 2006; Zhang, 2005). To date, influences of the MJO on the physical component of the global climate system have been well recognized and documented, and have also been well understood in some cases (e.g., monsoon, ENSO, hurricane, and extratropical weather). However, the impact of the MJO on atmospheric composition has been realized only recently (Ziemke and Chandra, 2003; Tian et al., 2007, 2008, 2011; Wong and Dessler, 2007; Li et al., 2010; Weare, 2010). Please see a recent review on this topic by Tian and Waliser (2011).

In the case of ozone, Tian et al. (2007) documented the spatial and temporal patterns of the tropical total column ozone $\left(\mathrm{O}_{3}\right)$ in connection with large-scale MJO convection and circulation anomalies. It was found from the measurements of the Total Ozone Mapping Spectrometer (TOMS; Stolarski and Frith, 2006) and the Atmospheric Infrared Sounder (AIRS; Chahine et al., 2006) that the total column $\mathrm{O}_{3}$ anomalies of 5-10 DU are mainly evident over the subtropics in the Pacific Ocean and the eastern hemisphere. The subtropical positive (negative) total column $\mathrm{O}_{3}$ anomalies flank or lie to the west of equatorial suppressed (enhanced) MJO convection and propagate slowly eastward $\left(\sim 5 \mathrm{~m} \mathrm{~s}^{-1}\right)$. The subtropical total column $\mathrm{O}_{3}$ anomalies are typically collocated with the subtropical upper-tropospheric 
cyclones/anticyclones and are anticorrelated with geopotential height anomalies near the tropopause. This indicates that the subtropical total column $\mathrm{O}_{3}$ anomalies are dynamically driven by the vertical movement of the subtropical tropopause layer and mainly associated with the $\mathrm{O}_{3}$ variability in the stratosphere rather the troposphere.

A number of additional studies have examined vertical structure of ozone variation in the upper troposphere and lower stratosphere that may be related to the MJO. Based on ozonesonde data in Indonesia, Fujiwara et al. (1998) suggested that the upper tropospheric ozone enhancement is tied to the passage of Kelvin waves and the MJO. In studying an "Ozone Mini-Hole" (OMH) event over the Tibetan Plateau during December 2003, Liu et al. (2009) found that the majority of ozone reduction of that OMH event was located in the upper troposphere and lower stratosphere based on the Michelson Interferometer for Passive Atmospheric Sounding (MIPAS; Cortesi et al., 2007) and Global Ozone Monitoring by Occultation of Stars (GOMOS; Kyrola et al., 2004) ozone profile data. Further analysis indicates that this ozone reduction in the upper troposphere and lower stratosphere is a result of the uplift of the tropopause by the upper-tropospheric anticyclone over the Tibetan Plateau induced by an MJO event over the equatorial Indian Ocean and western Pacific. A recent work of Weare (2010) also found significant stratospheric ozone variations associated with MJO using ERA-40 reanalysis ozone data. These results appear to be consistent with Tian et al. (2007) that the subtropical intraseasonal total column ozone anomalies are mainly associated with vertical movement of subtropical tropopause. To further understand the relative contribution of $\mathrm{O}_{3}$ from different atmospheric layers, especially stratosphere versus troposphere, to the subtropical total column $\mathrm{O}_{3}$ anomalies, we use contemporary satellite observations and in-situ measurements to investigate the vertical structure of subtropical $\mathrm{O}_{3}$ variations related to the MJO. In particular, we use vertical $\mathrm{O}_{3}$ profiles derived from the Earth Observing System (EOS) Microwave Limb Sounder (MLS) and Tropospheric Emission Spectrometer (TES) on Aura satellite and measured in-situ by the Southern Hemisphere Additional Ozonesondes (SHADOZ) project. Section 2 describes the data used in this study. Section 3 briefly describes the methodology adopted. Section 4 presents the main results, followed by a summary in Sect. 5 .

\section{Data}

In this study, we use the Level-2 (L2) v2.2 $\mathrm{O}_{3}$ product (Livesey et al., 2008) from the EOS MLS measurement from 1 November 2004-6 February 2010. The MLS instrument (Waters et al., 2006) was launched in 2004 on the NASA Aura satellite into a sun-synchronous near-polar orbit with equatorial crossing times of 01:43 and 13:43 local solar time. The MLS $\mathrm{O}_{3}$ product is retrieved from observations of atmospheric thermal emission near $240 \mathrm{GHz}$ using a limb-viewing geometry. Profiles are retrieved every $165 \mathrm{~km}$ along the sub- orbital track on 6 levels per decade of pressure from $215 \mathrm{hPa}$ through the stratosphere, with vertical resolution of $\sim 3 \mathrm{~km}$ in the upper troposphere. These profiles have been screened per the MLS data quality document (Livesey et al., 2007) and gridded by averaging data over $5^{\circ}$ longitude $\times 4^{\circ}$ latitude into daily values. With this gridding resolution the global coverage is completed in about 1 week. No criterion has been applied to select the line of sight angles or the solar zenith angels. Given the relatively long wavelengths of MLS observations, retrievals are negligibly perturbed by many clouds that strongly perturb observations at infrared and visible wavelengths. Recommended screening is generally successful in removing $\mathrm{v} 2.2$ profiles that are significantly impacted by scattering from large ice particle in convective cores (Schwartz et al., 2008).

The $\mathrm{L}_{2} \mathrm{O}_{3}$ profiles measured by TES from 20 September 2004 to 18 August 2008 (Beer et al., 2001; Jourdain et al., 2007; Worden et al., 2007) are also used in this study. TES is an infrared Fourier-transform spectrometer also aboard the Aura satellite, covering the spectral range $650-3050 \mathrm{~cm}^{-1}$ (3.3-15.4 mm) (Beer, 2006). It has a high spectral resolution at $0.025-0.1 \mathrm{~cm}^{-1}$ and a horizontal swath footprint of $5.3 \mathrm{~km} \times 0.53 \mathrm{~km} . \mathrm{O}_{3}$ profiles are retrieved from the infrared channels covering the $\mathrm{O}_{3} v_{3}$ band $\left(1050 \mathrm{~cm}^{-1}\right.$ or $\left.9.6 \mathrm{~mm}\right)$ using a non-linear optimal estimation algorithm (Rodgers, 2000; Worden et al., 2004; Bowman et al., 2006) on 67 pressure levels between the surface and $5 \mathrm{hPa}$, with a vertical spacing of $\sim 0.7 \mathrm{~km}$ below $10 \mathrm{hPa}$. These infrared channels are most sensitive to $\mathrm{O}_{3}$ at levels between 900 and $30 \mathrm{hPa}$ with a vertical resolution of $6 \mathrm{~km}$ for clear sky scenes. The retrieved TES tropospheric $\mathrm{O}_{3}$ profiles have been validated with SHADOZ ozonesonde measurements (Worden et al., 2007). When and where there are optically thick clouds, the TES retrieved $\mathrm{O}_{3}$ profiles below the optically thick clouds comes mainly from the a priori $\mathrm{O}_{3}$ profile because the retrieved $\mathrm{O}_{3}$ information below the cloud tops can be very low (Kulawik et al., 2006; Eldering et al., 2008). For this study, the TES swath $\mathrm{O}_{3}$ data were binned into the same $5^{\circ}$ longitude $\times 4^{\circ}$-latitude grid boxes of MLS described above. The global coverage is completed also in about 1 week at this gridding resolution. The number of individual retrievals being averaged in each grid box is recorded and served as weighting in the MJO-composite averaging.

To compare the MJO modulations in $\mathrm{O}_{3}$ as observed by MLS and TES, we also study the MJO modulations in the Level-3 (L3) total column $\mathrm{O}_{3}$ data derived from the Ozone Monitoring Instrument (OMI; Levelt et al., 2006b) aboard Aura during 1 November 2004-28 February 2010. OMI is an extension of the TOMS instrument. Total column $\mathrm{O}_{3}$ are retrieved from OMI radiances in the spectral region $307-332 \mathrm{~nm}$ and $359-361 \mathrm{~nm}$ (Levelt et al., 2006a). The original $\mathrm{OMI} \mathrm{O}_{3}$ column has been averaged daily into $0.25^{\circ}$-longitude $\times 0.25^{\circ}$-latitude grid boxes. As for TES, we regridded the daily data into the same $5^{\circ}$-longitude $\times 4^{\circ}$ latitude grid boxes of MLS. 
Table 1. Datasets used in this work. MLS Level-2 (L2) v2.2 $\mathrm{O}_{3}$ and TES L2 $\mathrm{O}_{3}$ are swaths products. They have been regridded into $5^{\circ}$-longitude $\times 4^{\circ}$-latitude daily products in this work. OMI Level-3 (L3) $\mathrm{O}_{3}$ and TRMM $3 \mathrm{~B} 42$ rainfall has also been regridded into $5^{\circ}$ longitude $\times 4^{\circ}$-latitude and $2.5^{\circ}$-longitude $\times 2^{\circ}$-latitude daily products, respectively, in this work (see text). Fiji is located at $\left(178.40^{\circ} \mathrm{E}\right.$, $\left.18.13^{\circ} \mathrm{S}\right)$.

\begin{tabular}{|c|c|c|c|}
\hline Name & Time Span (DD/MM/YYYY) & Original Resolution & Reprocessed Resolution \\
\hline MLS L2 $\mathrm{O}_{3}$ & $01 / 11 / 2004-06 / 02 / 2010$ & Swath & Daily, $5^{\circ}$ lon $\times 4^{\circ}$ lat \\
\hline TES L2 $\mathrm{O}_{3}$ & $20 / 09 / 2004-18 / 08 / 2008$ & Swath & Daily, $5^{\circ}$ lon $\times 4^{\circ}$ lat \\
\hline OMI L3 $\mathrm{O}_{3}$ & 01/11/2004-28/02/2010 & $\begin{array}{l}\text { Gridded daily, } \\
0.25^{\circ} \text { lon } \times 0.25^{\circ} \text { lat }\end{array}$ & Daily, $5^{\circ}$ lon $\times 4^{\circ}$ lat \\
\hline $\begin{array}{l}\mathrm{SHADOZ} \mathrm{O}_{3} \\
\text { over Fiji }\end{array}$ & 01/01/1998-31/12/2008 & Weekly/biweekly & - \\
\hline $\begin{array}{l}\text { TRMM 3B42 } \\
\text { rainfall }\end{array}$ & 01/11/2004-28/02/2010 & $\begin{array}{l}\text { Gridded 3-hourly, } \\
0.25^{\circ} \text { lon } \times 0.25^{\circ} \text { lat }\end{array}$ & Daily, $2.5^{\circ}$ lon $\times 2^{\circ}$ lat \\
\hline $\begin{array}{l}\text { ERA-Interim } \\
\text { GPH }_{150}\end{array}$ & 01/11/2004-31/01/2010 & $\begin{array}{l}\text { Gridded 3-hourly, } \\
1.25^{\circ} \text { lon } \times 1.25^{\circ} \text { lat }\end{array}$ & - \\
\hline
\end{tabular}

The SHADOZ project (Thompson et al., 2004, 2007) has collected over several thousand vertical $\mathrm{O}_{3}$ profiles from the troposphere to the middle stratosphere since 1998 from 14 tropical and subtropical sites using balloon-borne electrochemical concentration cell (ECC) ozonesondes. Among all the SHADOZ sites, Fiji $\left(178.40^{\circ} \mathrm{E}, 18.13^{\circ} \mathrm{S}\right)$ is the best site for this work because the data there are available from January 1998 to December 2008 between the surface and the mid-stratosphere $(\sim 20 \mathrm{hPa})$ and it lies in an area that was found to have strong MJO-driven total $\mathrm{O}_{3}$ variability (Tian et al., 2007).

To indicate the spatial patterns and propagation characteristics of the equatorial convective anomalies associated with the MJO, we use Tropical Rainfall Measuring Mission (TRMM) 3B42 rainfall data from 1 November 2004 to 28 February 2010. The TRMM 3B42 rainfall data are estimated from multiple satellites as well as gauge analyses where feasible at fine scales $\left(0.25^{\circ} \times 0.25^{\circ}\right.$ and 3 hourly) (Huffman et al., 2007). For this work, the rainfall data are averaged daily on $2.5^{\circ}$ longitude $\times 2.0^{\circ}$ latitude grids. To indicate the vertical movements of the subtropical tropopause related to the MJO, the 150-hPa geopotential height $\left(\mathrm{GPH}_{150}\right)$ from the European Centre for Medium-range Weather Forecasting (ECMWF) Interim reanalysis product (ERA-Interim; Dee et al., 2011) from 1 November 2004 to 31 January 2010 is used. No post-process has been applied to the $\mathrm{GPH}_{150}$ data.

We summarize the properties of the above datasets in Table 1 .

\section{Methods}

To capture the MJO signal in the $\mathrm{O}_{3}$ data, a running-average band-pass filter for 15-90 days is first applied to the time series. Then, to identify MJO events for producing a composite analysis, the All-season Real-time Multivariate MJO (RMM) daily index developed by Wheeler and Hendon (2004) is used. The RMM index consists of a pair of principle component time series, called $\mathrm{RMM}_{1}$ and $\mathrm{RMM}_{2}$, which are the projection of the daily observed NOAA outgoing longwave radiation (OLR) and NCEP/NCAR reanalysis and/or Australian Bureau of Meteorology Research Center Global Analysis and Prediction (GASP) analysis 850- and 200-hPa zonal winds, with the annual cycle and components of interannual variability removed, on a pair of multiple-variable EOFs. Two such EOFs are the leading pair of EOFs of the combined daily intraseasonal filtered fields of near-equatorially averaged $\left(15^{\circ} \mathrm{S}-15^{\circ} \mathrm{N}\right)$ NOAA OLR and NCEP/NCAR 850and 200-hPa zonal winds for all seasons from 1979 to 2001 (23 yr) and describe the key features of MJO. This daily index characterizes the state of the MJO in terms of its amplitude and phase, where the latter divides the MJO cycle (typically about 40-55 days) into 8 phases, each roughly lasting about 6 days. Phase 1 represents developing positive rainfall anomalies in the western Indian Ocean, with the sequential progression to Phase 8 corresponding to the eastward propagation of positive rainfall anomalies across the eastern Indian Ocean, Maritime Continent, western Pacific, and onto the central/eastern Pacific Ocean (Hendon and Salby, 1994). In this study, composite MJO cycles of interested quantities, such as rainfall, $\mathrm{O}_{3}$, and geopotential height, are produced by separately averaging together all daily values of the given quantity for each phase of the MJO, considering only strong amplitude events where $\mathrm{RMM}_{1}^{2}+\mathrm{RMM}_{2}^{2} \geq 1$. This compositing procedure, or closely analogous ones, has become a common methodology for examining impacts associated with the MJO (Tian et al., 2010, and references therein).

Since the MJO is strongest during boreal winters (November-April) when the influence from the Asian Monsoon is minimal (Zhang and Dong, 2004), we are only interested in the MJO events during this season. During 


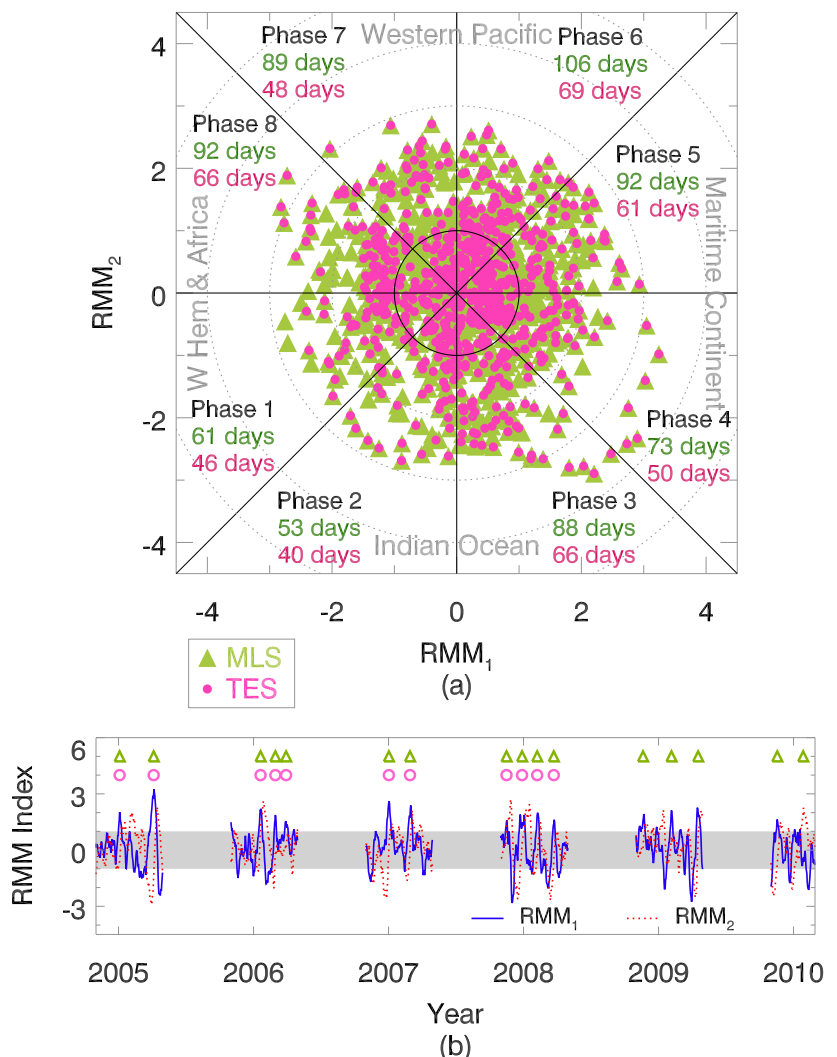

(b)

Fig. 1. (a) The number of days constituting each MJO phase during the observational periods of interest. Only days with strong MJO activity $\left(\mathrm{RMM}_{1}^{2}+\mathrm{RMM}_{2}^{2} \geq 1\right)$ are considered. The green triangles represent days with MLS $\mathrm{O}_{3}$ observations during the boreal winters (Novembers-Aprils) of November 2004-February 2010; the red dots represent days with TES $\mathrm{O}_{3}$ observations during the boreal winters of September 2004-August 2008. (b) The time series of RMM indices. The strong MJO events during the observational periods are denoted by the triangles and circles for MLS and TES, respectively. The indices lying in the grey region are considered to be weak MJO events and are ignored in the analysis.

November 2004-February 2010 when the $\mathrm{MLS} \mathrm{O}_{3}$ measurements are used in this work, there are $\sim 16$ strong MJO events during boreal winters, which constitute 53-106 days in each of the 8 phases (Fig. 1, green triangles). As a result, a total of 50-120 MLS soundings are averaged in the grid boxes for each phase (Fig. 2a). Similarly, during November 2004February 2008 when the TES $\mathrm{O}_{3}$ measurements are used in this work, there are $\sim 11$ strong MJO events during boreal winters, which constitute 40-69 days in each of the 8 phases (Fig. 1, pink dots). Because TES has much lower horizontal resolution, only a total of 10-30 TES soundings are averaged in the grid boxes for each phase (Fig. 2b).

\section{Results and discussion}

To examine the MJO variability of the stratospheric $\mathrm{O}_{3}$, the $\mathrm{O}_{3}$ anomalies associated with the MJO are integrated from 30-200 hPa to give the "stratospheric" column anomalies. It should be noted that for TES, the averaging kernels near $200 \mathrm{hPa}$ might have a significant tropospheric component in the tropics and subtropics. This may give rise to some of the differences between TES and MLS. An alternative would be to use $100 \mathrm{ppb}$ ozone to determine the bottom level for the stratospheric column. For simplicity and a qualitative investigation, we adopt the former definition in this work.

The intraseasonal variability in stratospheric column $\mathrm{O}_{3}$ can be seen clearly from the unfiltered seasonal anomalies. As an example, Fig. 3 shows the deseasonalized (cyan) time series over Fiji observed by MLS. The MLS $\mathrm{O}_{3}$ anomalies are obtained by averaging the swath footprints that fall into the $10^{\circ}$-longitude $\times 8^{\circ}$-latitude box centered at Fiji. MLS has almost daily coverage over the enclosed region. The orange line is the bandpassed time series, which resembles the intraseasonal variability in the raw time series.

By averaging over individual MJO phases during boreal winters, the spatial patterns of the MJO-modulation in the stratospheric $\mathrm{O}_{3}$ columns for MLS and TES are obtained and they are shown Fig. 4a and b, respectively (color shades). For brevity, only MJO phases 1, 3, 5, and 7 are plotted; and for clarity a 1-2-1 running average over MJO phase is applied. For example, the Phase 1 map shown is an average of phases 8,1 (doubly counted), and 2. Furthermore, a $20^{\circ}$-longitude $\times 10^{\circ}$-latitude spatial running average have been applied to remove high wavenumber fluctuations of $\mathrm{O}_{3}$ anomalies. To illustrate the convective activities, the MJOcomposite rainfall anomalies are overlaid as red and green solid contours with a $10^{\circ}$-longitude $\times 6^{\circ}$-latitude spatial running average applied. The propagation pattern of rainfall is consistent with those delineated in previous studies using the extended empirical orthogonal functions (EEOF) (Waliser et al., 2005; Tian et al., 2007). Therefore, we expect that the MJO patterns obtained from EEOF and MEOF will be similar (Tian et al., 2010). The MJO-composite $\mathrm{GPH}_{150}$ anomalies are shown as solid and dotted black contours with a $9^{\circ}$ longitude $\times 6^{\circ}$-latitude spatial running average applied.

Tian et al. (2007) examined the MJO in TOMS and AIRS total $\mathrm{O}_{3}$ columns using EEOF (see their Figs. 1 and 2). Their Lag -2 (+4) corresponds roughly to our Phase 1 (7). In general, the spatial-temporal patterns of the stratospheric $\mathrm{O}_{3}$ column anomalies of the MJO composites for MLS and TES are similar to those in total $\mathrm{O}_{3}$ of TOMS and AIRS. During Phase $1(\operatorname{Lag}-2)$, enhanced convection as indicated by positive rainfall anomalies is found in the western equatorial Indian Ocean. In contrast, suppressed convection as indicated by negative rainfall anomalies resides over the equatorial Indo-Pacific Warm Pool. As a result, upper-tropospheric cyclonic gyres are formed over Asia and the western Pacific on the northern subtropics as well as the eastern Indian Ocean 
(a) MLS

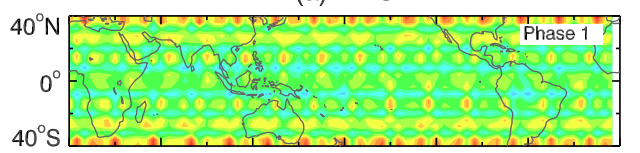

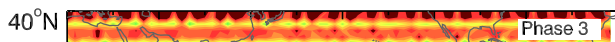

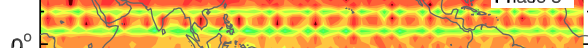

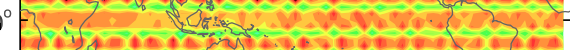

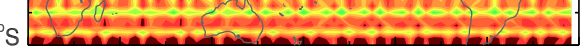
$40^{\circ} \mathrm{N} \rightarrow \mathrm{N}$ Phase 5

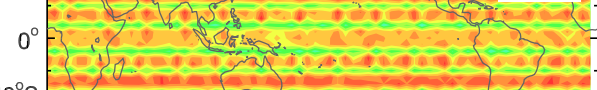

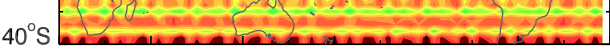

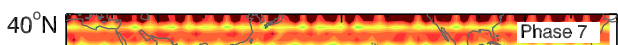

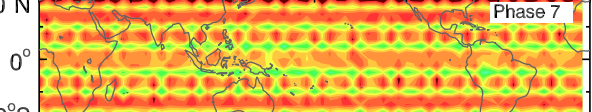

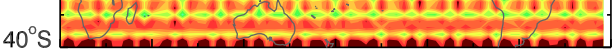

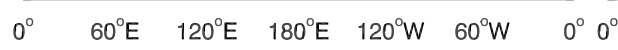

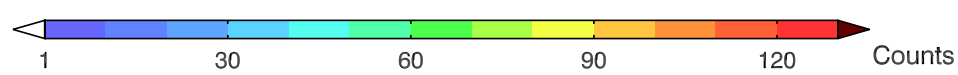

(b) TES
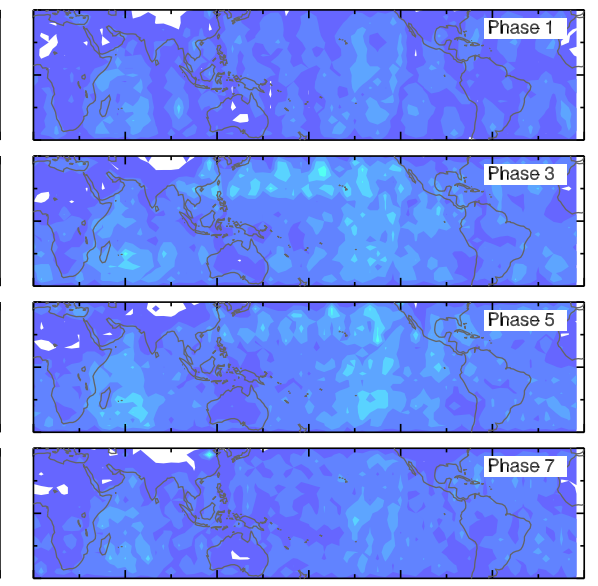

$\begin{array}{llllll}60^{\circ} \mathrm{E} & 120^{\circ} \mathrm{E} & 180^{\circ} \mathrm{E} & 120^{\circ} \mathrm{W} & 60^{\circ} \mathrm{W} & 0^{\circ}\end{array}$

Fig. 2. Number of MLS/TES soundings in each MJO phase during the observational periods of interest. The patterns of MLS statistics in (a) appear to be discretized in space because the MLS profiles are retrieved every $165 \mathrm{~km}$ along the sub-orbital track, which is approximately $1.5^{\circ}$ latitude in the equatorial region.

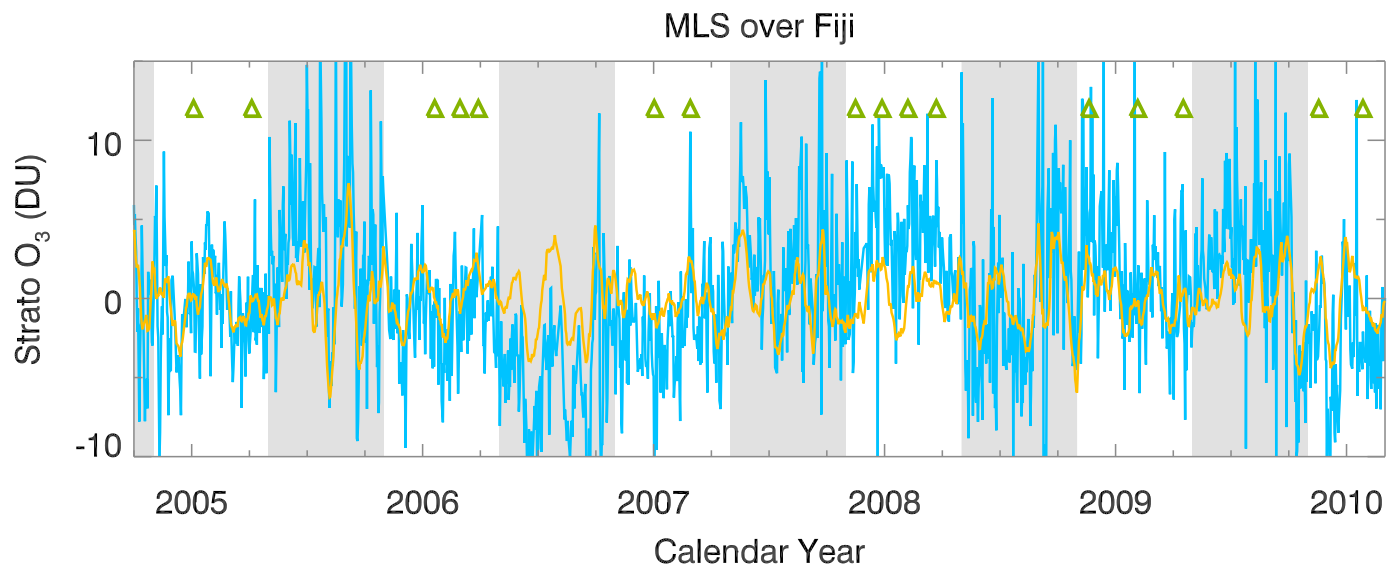

Fig. 3. The deseasonalized (cyan) and the bandpassed (orange) time series over Fiji observed by MLS. The grey shades are the boreal summer seasons (May-August), when data have been ignored in the MJO-phase averages. The strong MJO events during the observational periods are denoted by the triangles for MLS as in Fig. $1 \mathrm{~b}$.

and Australia on the southern subtropics, both on the west side of the equatorial suppressed convection (e.g. Hendon and Salby, 1994). These subtropical cyclones induce downward movements of subtropical tropopause as indicated by negative $\mathrm{GPH}_{150}$ anomalies. Thus, both MLS and TES show positive stratospheric $\mathrm{O}_{3}$ column anomalies (a few Dobson units; c.f. Fig. 5) over these subtropical regions.

During Phase 3 (Lag 0), the enhanced convection becomes stronger and wider and it moves to the eastern equatorial Indian Ocean and Maritime Continent and the suppressed convention becomes weaker and narrower and it moves to the South Pacific Convergence Zone (SPCZ). As a result, upper-tropospheric anticyclonic gyres are formed over the
Middle East on the northern subtropics as well as the southern subtropical Africa, both on the west side of the equatorial enhanced convection. They induce upward movements of subtropical tropopause as indicated by positive $\mathrm{GPH}_{150}$ anomalies and negative stratospheric $\mathrm{O}_{3}$ column anomalies over these subtropical regions as shown by both MLS and TES. Phases 5 and $7(\mathrm{Lag}+2$ and Lag +4$)$ are very similar to Phases 1 and 3, respectively, except for an opposite sign. These spatial patterns of rainfall, $\mathrm{GPH}_{150}$ and $\mathrm{O}_{3}$ anomalies move eastward with a speed of $\sim 5 \mathrm{~m} \mathrm{~s}^{-1}$ from Phases 1 to 7. The subtropical stratospheric $\mathrm{O}_{3}$ column anomalies for $14^{\circ} \leq \mid$ latitudes $\mid \leq 34^{\circ}$ are moderately anticorrelated with the subtropical $\mathrm{GPH}_{150}$ anomalies in both MLS and TES with 
(a) MLS

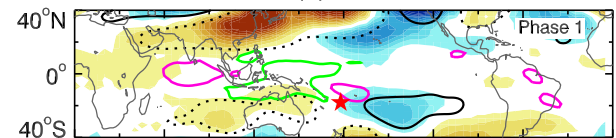

$40^{\circ} \mathrm{N}+\ldots . . .1 \%$ Phase 3
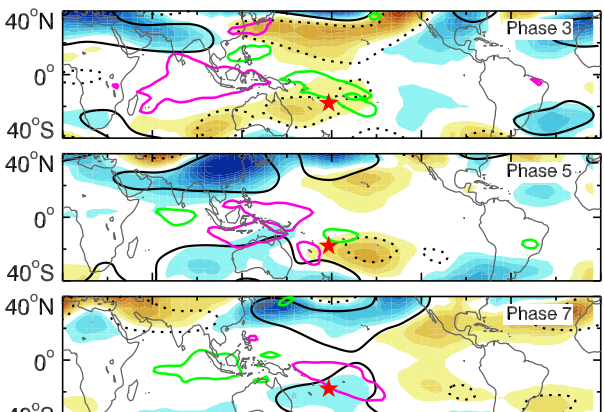

$40^{\circ} \mathrm{S}$ (b) TES
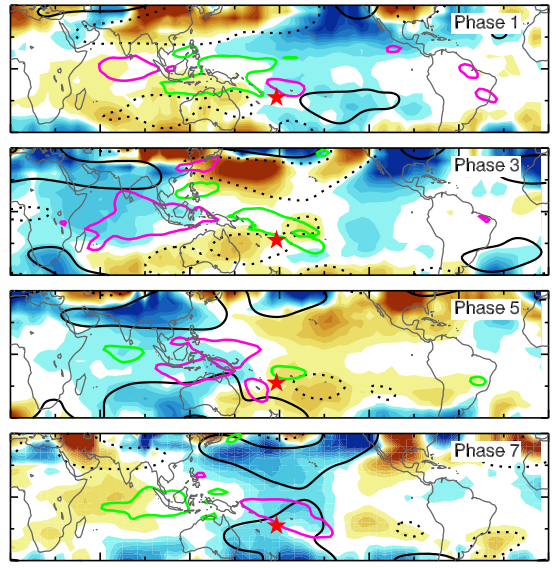

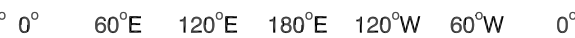
Strato $\mathrm{O}_{3}$ Column at $30-200 \mathrm{hPa}$ (DU; color shades)

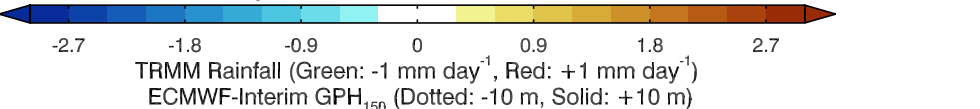

Fig. 4. MJO-related stratospheric $\mathrm{O}_{3}$ anomalies integrated between $30-200 \mathrm{hPa}$ in color shades derived from (a) MLS and (b) TES. For simplicity, only MJO phases 1, 3, 5 and 7 are plotted with a 1-2-1 running average applied (see text). Furthermore, a $20^{\circ}$-longitude $\times 10^{\circ}$ latitude spatial running average has been applied to remove high wavenumber fluctuations of $\mathrm{O}_{3}$ anomalies. The MJO-related rainfall anomalies are overlaid as red $\left(+1 \mathrm{~mm} \mathrm{day}^{-1}\right)$ and green $\left(-1 \mathrm{~mm}\right.$ day $\left.^{-1}\right)$ solid contours with a $10^{\circ}$-longitude $\times 6^{\circ}$-latitude spatial running average applied. The MJO-related 150-hPa geopotential height $\left(\mathrm{GPH}_{150}\right)$ anomalies are shown as solid $(+10 \mathrm{~m})$ and dotted $(-10 \mathrm{~m})$ black contours with a $9^{\circ}$-longitude $\times 6^{\circ}$-latitude spatial running average applied. The location of Fiji $\left(178.4^{\circ} \mathrm{E}, 18.13^{\circ} \mathrm{S}\right)$ is represented by $(\star)$.

(a) MLS

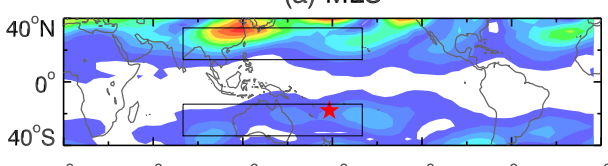

$0^{\circ}$ (b) TES

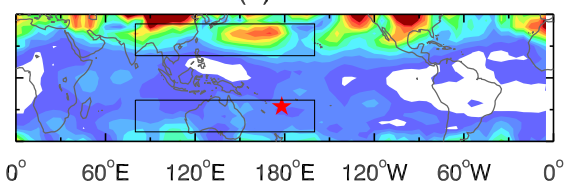

Fig. 5. The MJO variability in $\mathrm{O}_{3}$ columns derived from MLS and TES observations. The variability is defined as 2 standard deviations of the MJO cycle (see text). The location of Fiji $\left(178.4^{\circ} \mathrm{E}, 18.13^{\circ} \mathrm{S}\right)$ is represented by $(\star)$. The rectangular boxes enclose representative subtropical regions $\left(80^{\circ} \mathrm{E}-200^{\circ} \mathrm{E}, 14^{\circ} \mathrm{N} / \mathrm{S}-34^{\circ} \mathrm{N} / \mathrm{S}\right)$ where the $\mathrm{MJO}$ modulations are largest.

linear correlation coefficients of -0.75 for MLS and -0.60 for TES, respectively.

The MJO variability of stratospheric $\mathrm{O}_{3}$ at the grid points derived from MLS and TES $\mathrm{O}_{3}$ observations are shown in Fig. 5. It is defined as two standard deviations of the 8-phase MJO cycles in the enclosed regions, which roughly equates the amplitude of the MJO cycle. For both observations, the MJO variability at the subtropical regions ( $\mid$ latitudes $\mid>15^{\circ}$ ) is larger than those in the deep tropics (|latitudes $\mid \leq 15^{\circ}$ ). In the northern subtropics, the MJO variability is generally 5$8 \mathrm{DU}$ near the Indo-Pacific region whereas in the southern subtropics, it is 1-2 DU. In other words, the MJO variability in the northern subtropics is generally a factor of 2-4 larger than those in the southern subtropics. This north-south gradi- ent is also evident in the TOMS column $\mathrm{O}_{3}$ data reported in Tian et al. (2007). As will be discussed below, this gradient is also found in the recent OMI column $\mathrm{O}_{3}$ data. The MJO variability in the deep tropics as observed by TES $(\sim 1 \mathrm{DU})$ is slightly larger than that as observed by MLS ( $<0.5 \mathrm{DU})$. This may be partly due to the fact that TES $\mathrm{O}_{3}$ concentration may have a significant tropospheric component, where the MJO modulations in the tropospheric $\mathrm{O}_{3}$ may be due to different mechanisms that are out of the scope of this work.

To quantify the relative contributions of the stratospheric versus tropospheric $\mathrm{O}_{3}$ to the observed MJO modulations in the total column $\mathrm{O}_{3}$, representative subtropical regions where the MJO modulations are largest in the respective hemispheres are chosen. These regions are defined 
(a) $\operatorname{MLS}\left(80^{\circ} \mathrm{E}-200^{\circ} \mathrm{E}\right)$

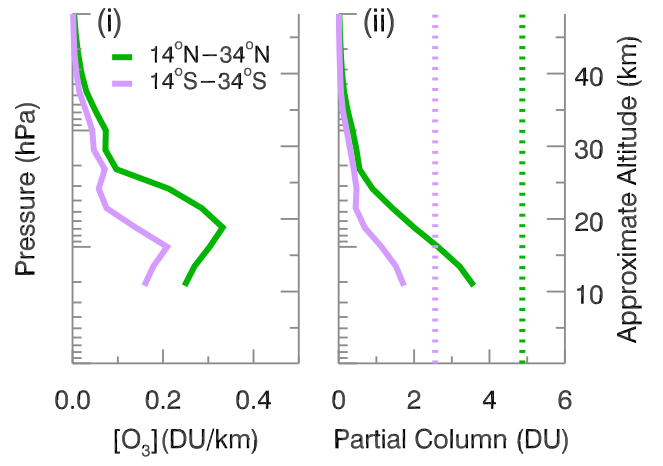

(b) TES $\left(80^{\circ} \mathrm{E}-200^{\circ} \mathrm{E}\right)$

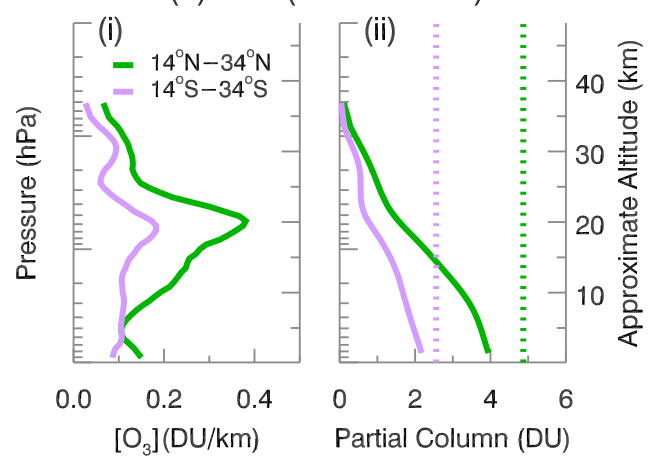

Fig. 6. (a)(i) Regional MJO variability of $\mathrm{O}_{3}$ concentration (in unit of DU km-1) derived from MLS measurements in regions $\left(80^{\circ} \mathrm{E}-\right.$ $200^{\circ} \mathrm{E}, 14^{\circ} \mathrm{N} / \mathrm{S}-30^{\circ} \mathrm{N} / \mathrm{S}$ ), which are enclosed by the rectangular boxes in Fig. 5. As in Fig. 5, the variability is defined as 2 standard deviations of the MJO cycle; (a)(ii) Regional MJO variability of partial $\mathrm{O}_{3}$ columns integrated from $30 \mathrm{hPa}$ to pressure levels below. (b) Same as (a) except for TES.

as $80^{\circ} \mathrm{E}-200^{\circ} \mathrm{E}, 14^{\circ} \mathrm{N} / \mathrm{S}-34^{\circ} \mathrm{N} / \mathrm{S}$, which are enclosed in Fig. 5. The overall MJO variability in the vertical $\mathrm{O}_{3}$ concentrations there is shown in Fig. 6a(i) and b(i). For both MLS and TES, the MJO modulations have a peak in the lower stratosphere near the tropopause at $\sim 100 \mathrm{hPa}$. The maximum variations are $\sim 0.4 \mathrm{DU} \mathrm{km}^{-1}$ and $\sim 0.2 \mathrm{DU} \mathrm{km}^{-1}$ for the northern and southern subtropics, respectively. This supports the idea that the MJO modulations found in TOMS and AIRS total $\mathrm{O}_{3}$ column are related to the vertical displacements of the tropopause. In the northern hemisphere, the altitude where the signal peaks at for MLS is the same as that for TES. But in the southern hemisphere, that altitude for MLS is slightly lower than that for TES by $\sim 2 \mathrm{~km}$. This difference is, however, within the vertical resolution, $\sim 6 \mathrm{~km}$, of TES near the tropopause.

Figure $6 \mathrm{a}$ (ii) and b(ii) show the MJO variability of the partially integrated $\mathrm{O}_{3}$ column from $30 \mathrm{hPa}$ to pressure levels below, including those in the troposphere. Both MLS and TES show variability of $\sim 4 \mathrm{DU}$ and $\sim 2 \mathrm{DU}$ at $\sim 150 \mathrm{hPa}$ in the northern and southern subtropical region, respectively. We compare the MJO modulations in $\mathrm{O}_{3}$ as observed by MLS and TES with that in the total column $\mathrm{O}_{3}$ data derived from OMI in Fig. 6a(ii) and b(ii). We applied the same bandpass filter and MJO compositing method to $\mathrm{OMI} \mathrm{O}_{3}$ column anomalies and obtained the MJO patterns. The variability in the regions defined above from OMI total $\mathrm{O}_{3}$ column are 5.0 and 2.6 DU in the northern and southern subtropical regions, respectively, which are $\sim 20 \%$ larger than those in the subtropical $\mathrm{O}_{3}$ column derived from MLS and TES. Although there are quantitative differences between OMI, MLS and TES measurements, qualitatively the above comparison shows that majority of the MJO variability in the total $\mathrm{O}_{3}$ column comes from the lower stratosphere and the factorof-2 difference in the MJO-amplitudes between the northern and southern subtropics seems robust.

TES $\mathrm{O}_{3}$ profiles also allow us to estimate the fractional MJO variability in the total $\mathrm{O}_{3}$ column due to the tropospheric components. From Fig. 6b(ii), the total cumulative MJO variability of $\mathrm{O}_{3}$ at the surface is $4.0 \mathrm{DU}$ and $2.2 \mathrm{DU}$ in the northern and southern subtropics, respectively. On the other hand, the corresponding cumulative MJO variability of $\mathrm{O}_{3}$ from surface to $200 \mathrm{hPa}$ is $1.1 \mathrm{DU}$ and $0.6 \mathrm{DU}$, or $24 \%$ and $27 \%$, in the northern and southern subtropics respectively.

Figure 7 shows the pressure-longitude cross sections of the MJO-related $\mathrm{O}_{3}$ anomalies in the northern subtropics averaged between $14^{\circ} \mathrm{N}$ and $30^{\circ} \mathrm{N}$ from both MLS and TES. A $20^{\circ}$-longitude spatial running average has been applied to remove high-wavenumber fluctuations. Overplotted are MJOrelated equatorial rainfall anomalies averaged between $5^{\circ} \mathrm{S}$ and $5^{\circ} \mathrm{N}$ from TRMM (solid lines) and MJO-related subtropical $\mathrm{GPH}_{150}$ anomalies averaged between $15^{\circ} \mathrm{N}$ and $30^{\circ} \mathrm{N}$ from ERA-Interim (dotted lines). Eastward propagations are seen in the anomalies of $\mathrm{O}_{3}$, rainfall and $\mathrm{GPH}_{150}$. The MJOamplitude of the equatorial rainfall is $\pm 2 \mathrm{~mm} \mathrm{day}^{-1}$. It has a positive anomaly in the western Indian Ocean in Phase 1 , which then propagates to the central Pacific in Phase 8. The corresponding MJO-amplitude of the northern subtropical $\mathrm{GPH}_{150}$ is $\pm 20 \mathrm{~m}$. The upper-tropospheric subtropical cyclones (negative $\mathrm{GPH}_{150}$ anomalies at Phase 3) lead the equatorial enhanced convection (Phase 6) while the latter leads the upper-tropospheric subtropical anticyclones (positive $\mathrm{GPH}_{150}$ anomalies at Phase 7) by 5-10 days. This is consistent with the relationship between the equatorial rainfall anomalies and subtropical $\mathrm{GPH}_{150}$ anomalies shown in Fig. 4. In general, positive $\mathrm{O}_{3}$ anomalies are found when $\mathrm{GPH}_{150}$ anomalies are negative in all phases, supporting the idea that the $\mathrm{O}_{3}$ anomalies are mainly related to dynamical motions. Both MLS and TES data indicate that the same sign of subtropical $\mathrm{O}_{3}$ anomalies at the same location can be found from $200 \mathrm{hPa}$ to $30 \mathrm{hPa}$ but the maximum $\mathrm{O}_{3}$ anomalies are approximately in the lower stratosphere. 


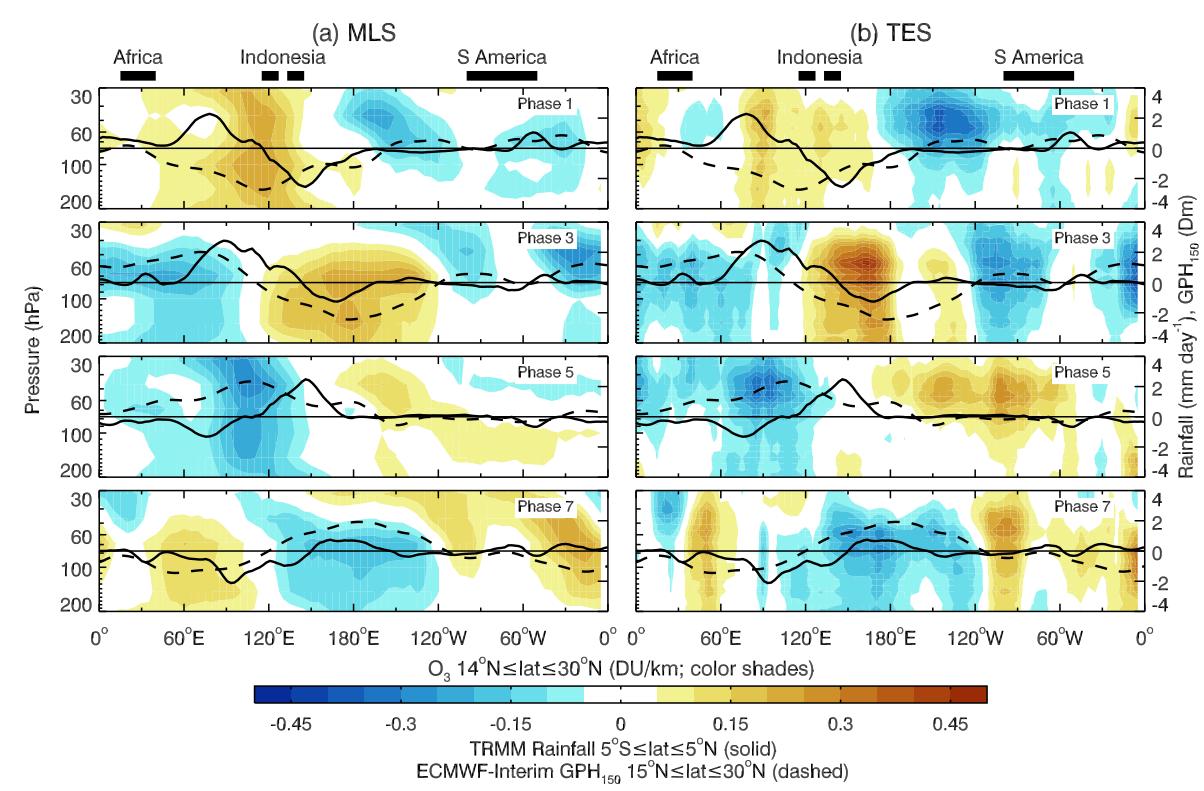

Fig. 7. Pressure-longitude cross sections of the MJO-related $\mathrm{O}_{3}$ anomalies in the northern subtropics averaged between $14^{\circ} \mathrm{N}$ and $30^{\circ} \mathrm{N}$ from both MLS (a) and TES (b) . A $20^{\circ}$-longitude spatial running average has been applied to remove high-wavenumber fluctuations. Solid lines denote the MJO-related TRMM rainfall anomalies averaged between $5^{\circ} \mathrm{S}$ and $5^{\circ} \mathrm{N}$. Dashed lines represent the MJO-related ERA-Interim $\mathrm{GPH}_{150}$ anomalies averaged between $15^{\circ} \mathrm{N}$ and $30^{\circ} \mathrm{N}$ in unit of decameters $(1 \mathrm{Dm}=10 \mathrm{~m})$.

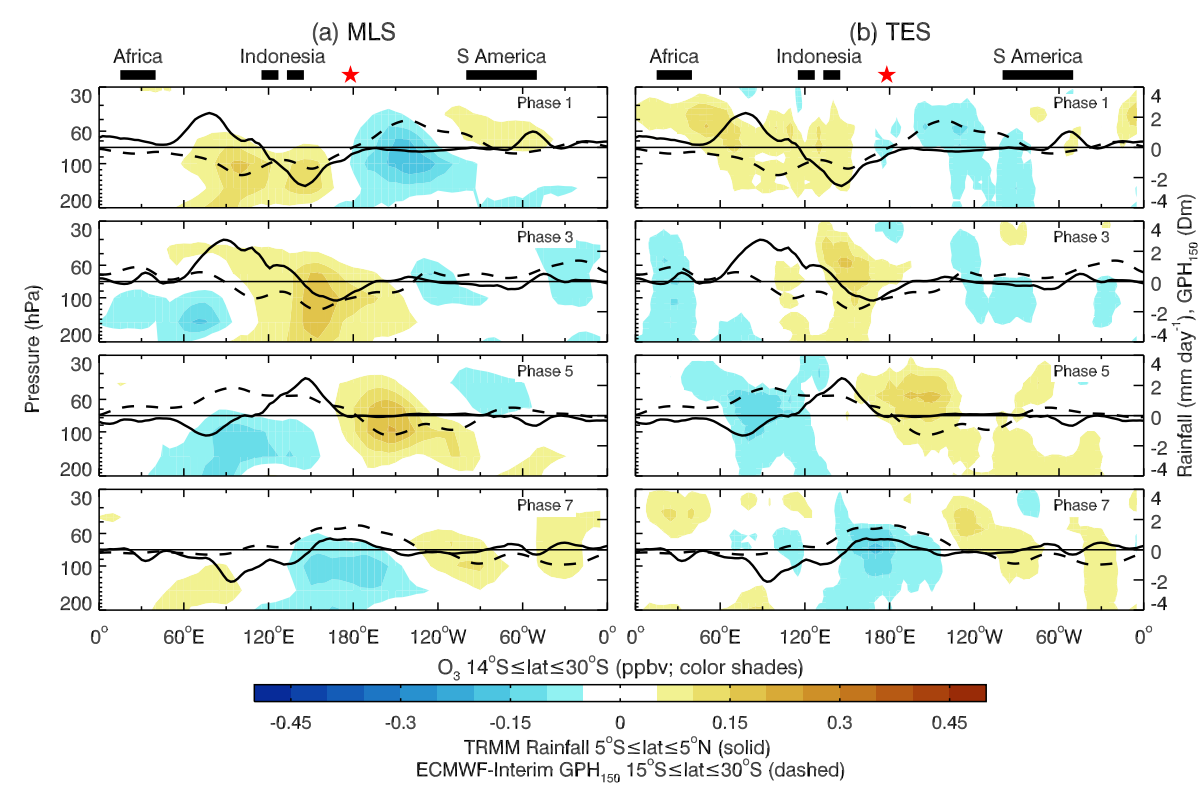

Fig. 8. As in Fig. 7 except for the southern subtropics. The $\mathrm{O}_{3}$ anomalies (color shades) are averaged between $14^{\circ} \mathrm{S}$ and $30^{\circ} \mathrm{S}$; the $\mathrm{GPH} 150$ anomalies (dashed) are averaged between $15^{\circ} \mathrm{S}$ and $30^{\circ} \mathrm{S}$. The location of Fiji $\left(178.4^{\circ} \mathrm{E}, 18.13^{\circ} \mathrm{S}\right)$ is denoted by the star $(\star)$.

Similar result is also found in the southern subtropical $\mathrm{O}_{3}$ anomalies between $14^{\circ} \mathrm{S}$ and $30^{\circ} \mathrm{S}$, which are shown in Fig. 8 . The same $20^{\circ}$-longitude spatial running average has been applied and MJO-related subtropical $\mathrm{GPH}_{150}$ anomalies from ERA-Interim (dotted lines) averaged between $15^{\circ} \mathrm{S}$ and $30^{\circ} \mathrm{S}$ are overplotted. The equatorial rainfall anomalies are the same as those in Fig. 7. Overall the eastward propagations of $\mathrm{O}_{3}$ and $\mathrm{GPH}_{150}$ are similar to those in the northern subtropics. The MJO-amplitude of southern subtropical $\mathrm{GPH}_{150}$ is comparable $( \pm 20 \mathrm{~m})$ to that in the northern subtropics. The $\mathrm{O}_{3}$ anomalies here, however, are only about half of those in the northern subtropics, as noted above. 
(a) MLS

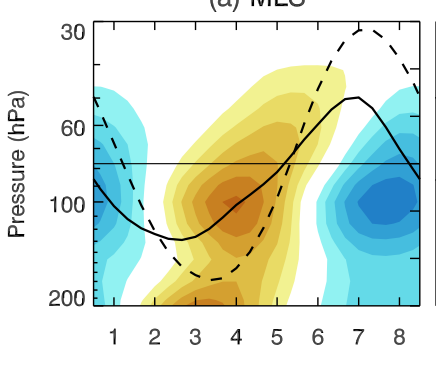

(b) TES

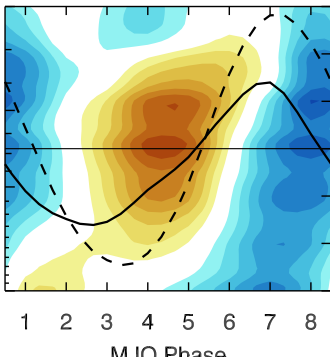

MJO Phase

$\mathrm{O}_{3}(\mathrm{DU} / \mathrm{km}$; color shades)

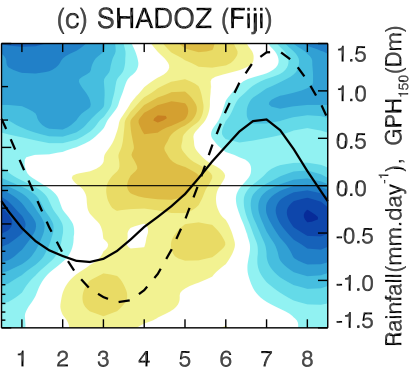

$\begin{array}{llllllll}1 & 2 & 3 & 4 & 5 & 6 & 7 & 8\end{array}$

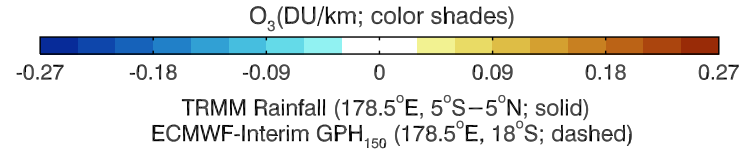

Fig. 9. Vertical structures of the $\mathrm{O}_{3}$ anomalies over Fiji $\left(178.40^{\circ} \mathrm{E}, 18.13^{\circ} \mathrm{S}\right)$ from (a) MLS, (b) TES and (c) SHADOZ as a function of MJO phase for the composite MJO life cycle. The MLS and TES $\mathrm{O}_{3}$ anomalies are obtained by averaging the swath footprints that fall into the $10^{\circ}$-longitude $\times 8^{\circ}$-latitude box centered at Fiji. Solid lines denote MJO-related rainfall anomalies from TRMM averaged between $5^{\circ} \mathrm{S}$ and $5^{\circ} \mathrm{N}$ at $178.5^{\circ} \mathrm{E}$. Dashed lines represent $\mathrm{GPH}_{150}$ anomalies at $\left(178.5^{\circ} \mathrm{E}, 18^{\circ} \mathrm{S}\right)$ from ERA-Interim.

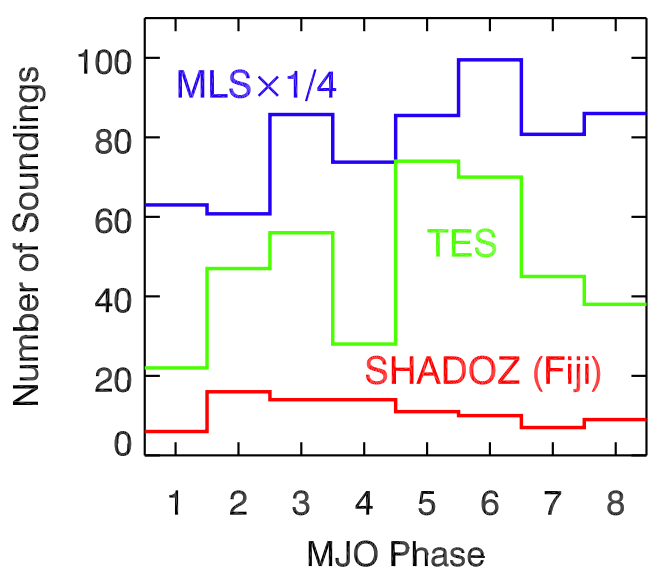

Fig. 10. The number of MLS (blue) and TES (green) swath footprints that fall into the $10^{\circ}$-longitude $\times 8^{\circ}$-latitude box centered at Fiji used in this study. The count of MLS has been scaled down by a factor of 4 . The number of SHADOZ ozonesonde measurements used in this study is shown in red.

As a form of validation, the vertical structures of the MJO-related $\mathrm{O}_{3}$ anomalies over Fiji $\left(178.40^{\circ} \mathrm{E}, 18.13^{\circ} \mathrm{S}\right)$ derived from MLS and TES are compared to that derived from SHADOZ and are shown in Fig. 9. The MLS $\mathrm{O}_{3}$ anomalies are obtained over the $10^{\circ}$-longitude $\times 8^{\circ}$-latitude box centered at Fiji, which is the same region that has been used to derive the time series in Fig. 3. There are in general 300-400 daily values being averaged in each MJO phase during the boreal winters (Fig. 10). The TES $\mathrm{O}_{3}$ anomalies are similarly obtained in the enclosed region. There are only $20-$ 80 daily values being averaged each phase due to its lower horizontal resolutions than that of MLS as discussed above. On average, TES provides about one daily observation or two per week over the box enclosing Fiji. On the other hand, for the SHADOZ project over Fiji, there is only one $\mathrm{O}_{3}$ measurement or two biweekly over the site. As a result, roughly 1020 daily values are averaged in each phase during the boreal winters. We applied the same band-pass filter to SHADOZ time series.

In Fig. 9, solid lines denote MJO-related rainfall anomalies from TRMM averaged between $5^{\circ} \mathrm{S}$ and $5^{\circ} \mathrm{N}$ at $178.5^{\circ} \mathrm{E}$. Dashed lines represent $\mathrm{GPH}_{150}$ anomalies at $\left(178.5^{\circ} \mathrm{E}, 18^{\circ} \mathrm{S}\right)$ from ERA-Interim. The equatorial rainfall anomalies at $178.5^{\circ} \mathrm{E}$ show a minimum in Phase 2 and a maximum in Phase 6. Meanwhile, the $\mathrm{GPH}_{150}$ anomalies have a minimum in Phase 4 and a maximum in Phase 7 . The MJO anomalies of MLS and TES $\mathrm{O}_{3}$ show a peak-to-trough amplitude of $\sim 0.35 \mathrm{DU} \mathrm{km}^{-1}$ at $\sim 100 \mathrm{hPa}$ and $\sim 80 \mathrm{hPa}$, respectively and their maximum amplitudes both occur in Phase 4. On the other hand, the $\mathrm{SHADOZ} \mathrm{O}_{3}$ anomaly shows a peak-to-trough amplitude $\sim 0.3 \mathrm{DU} \mathrm{km}^{-1}$ at $\sim 100 \mathrm{hPa}$. In general, the maximum MJO amplitudes in $\mathrm{SHADOZ} \mathrm{O}_{3}$ are attained in Phases 4-5. The quantitative differences between MLS/TES and SHADOZ may be due to the much lower sampling rates of SHADOZ. Moreover, there is a vertical tilt in the SHADOZ $\mathrm{O}_{3}$ anomaly, which is formed by the extension of a positive anomaly in Phase 3 at $200 \mathrm{hPa}$ to that in Phase 5 at $30 \mathrm{hPa}$. Qualitatively, there is also a hint of vertical tilt in the anomalies of both MLS and TES $\mathrm{O}_{3}$ concentrations. These agreements among MLS, TES, and SHADOZ indicate that the vertical structures of the $\mathrm{O}_{3}$ anomalies from MLS and TES, should be trustworthy to give insight into the objective posed by this study. 


\section{Summary and concluding remarks}

Tian et al. (2007) found that the MJO-related total column $\mathrm{O}_{3}$ anomalies are mainly evident over the subtropics in the Pacific Ocean and the Eastern Hemisphere. The subtropical total column $\mathrm{O}_{3}$ anomalies are typically collocated with the subtropical upper-tropospheric cyclones/anticyclones associated with the dynamics of the MJO and are anticorrelated with geopotential height anomalies near the tropopause. From these observational results, it was speculated that the subtropical total column $\mathrm{O}_{3}$ anomalies are mainly associated with the $\mathrm{O}_{3}$ variability in the stratosphere rather the troposphere. Vertical $\mathrm{O}_{3}$ profiles from MLS and TES provide a unique opportunity for examining this hypothesis and understanding the relative contribution of different atmospheric layers, especially stratosphere versus troposphere, to the subtropical total column $\mathrm{O}_{3}$ anomalies. The composite $\mathrm{MJO}$ analysis above suggests that the spatial-temporal patterns of the subtropical stratospheric $\mathrm{O}_{3}$ anomalies from MLS and TES are similar to those of the subtropical total column $\mathrm{O}_{3}$ anomalies from TOMS and AIRS as reported previously (Tian et al., 2007). In particular, the anomalies in the subtropical stratospheric $\mathrm{O}_{3}$ and those in the total column are both dynamically driven by the vertical movements of subtropical tropopause layer, characterized by the $\mathrm{GPH}_{150}$. The MJO modulations in subtropical $\mathrm{O}_{3}$ have peaks in the lower stratosphere in both MLS and TES data, but the peak of MLS $\mathrm{O}_{3}$ is located at the pressure level $100 \mathrm{hPa}$, which is lower than that of TES $\mathrm{O}_{3}$ located at $80 \mathrm{hPa}$. Furthermore, TES measurements show that $24-27 \%$ of the total $\mathrm{O}_{3}$ column anomalies are contributed by the tropospheric components. The strengths of the MJO modulations over Fiji derived from MLS and TES $\mathrm{O}_{3}$ roughly agree with that derived from the in-situ measurements by SHADOZ. This indicates that the subtropical total column $\mathrm{O}_{3}$ anomalies are mostly from the $\mathrm{O}_{3}$ anomalies in the lower stratosphere, which supports the hypothesis of Tian et al. (2007).

Currently $\mathrm{O}_{3}$ vertical profiles have also been retrieved from the Huggins band observed by OMI but these products are under development and evaluation (Liu, 2010a, b). Future work could involve an $\mathrm{O}_{3}$ budget analysis using a sophisticated chemical transport model and a similar study in the near-equatorial regions and/or tropospheric regions where the MJO signals in total $\mathrm{O}_{3}$ are weak and other source and sink processes may be playing larger and possibly compensating roles. This study demonstrates the potential for the MLS and TES $\mathrm{O}_{3}$ to improve our understanding of $\mathrm{O}_{3}$ dynamics and chemistry, and its effects on climate change. Given that the potential predictability of the MJO extends to lead times of 2-4 weeks (Waliser et al., 2003), the strong connection between the intraseasonal subtropical stratospheric $\mathrm{O}_{3}$ variations and the $\mathrm{MJO}$ implies that the stratospheric $\mathrm{O}_{3}$ variations may also be predictable with similar lead times over the subtropics.
Acknowledgements. This research was supported in part by the National Science Foundation (NSF) grant ATM-0840787 to California Institute of Technology (Caltech) and ATM-0840755 to University of California, Los Angeles. Part of this research was carried out at Jet Propulsion Laboratory, Caltech, under a contract with National Aeronautics and Space Administration. ERA-Interim data were obtained from the ECMWF Data Server (http://data.ecmwf.int/data/). The RMM index was obtained from the Bureau of Meteorology website (http://www.bom.gov.au/climate/mjo/). The SHADOZ data were obtained from SHADOZ data server (http://croc.gsfc.nasa.gov/shadoz/).

Edited by: G. Vaughan

\section{References}

Beer, R.: TES on the Aura mission: Scientific objectives, measurements, and analysis overview, IEEE T. Geosci. Remote, 44, 1102-1105, doi:10.1109/TGRS.2005.863716, 2006.

Beer, R., Glavich, T. A., and Rider, D. M.: Tropospheric emission spectrometer for the Earth Observing System's Aura Satellite, Appl. Optics, 40, 2356-2367, 2001.

Bowman, K. W., Rodgers, C. D., Kulawik, S. S., Worden, J., Sarkissian, E., Osterman, G., Steck, T., Lou, M., Eldering, A., Shephard, M., Worden, H., Lampel, M., Clough, S., Brown, P., Rinsland, C., Gunson, M., and Beer, R. Tropospheric emission spectrometer: Retrieval method and error analysis, IEEE T. Geosci. Remote, 44, 1297-1307, doi:10.1109/TGRS.2006871234, 2006.

Chahine, M. T., Pagano, T. S., Aumann, H. H., Atlas, R., Barnet, C., Blaisdell, J., Chen, L., Divakarla, M., Fetzer, E. J., Goldberg, M., Gautier, C., Granger, S., Hannon, S., Irion, F. W., Kakar, R., Kalnay, E., Lambrigtsen, B. H., Lee, S. Y., Le Marshall, J., McMillan, W. W., McMillin, L., Olsen, E. T., Revercomb, H., Rosenkranz, P., Smith, W. L., Staelin, D., Strow, L. L., Susskind, J., Tobin, D., Wolf, W., and Zhou, L. H.: Improving weather forecasting and providing new data on greenhouse gases, B. Am. Meteorol. Soc., 87, 911-926, doi:10.1175/BAMS-87-7-911, 2006.

Cortesi, U., Lambert, J. C., De Clercq, C., Bianchini, G., Blumenstock, T., Bracher, A., Castelli, E., Catoire, V., Chance, K. V., De Mazire, M., Demoulin, P., Godin-Beekmann, S., Jones, N., Jucks, K., Keim, C., Kerzenmacher, T., Kuellmann, H., Kuttippurath, J., Iarlori, M., Liu, G. Y., Liu, Y., McDermid, I. S., Meijer, Y. J., Mencaraglia, F., Mikuteit, S., Oelhaf, H., Piccolo, C., Pirre, M., Raspollini, P., Ravegnani, F., Reburn, W. J., Redaelli, G., Remedios, J. J., Sembhi, H., Smale, D., Steck, T., Taddei, A., Varotsos, C., Vigouroux, C., Waterfall, A., Wetzel, G., and Wood, S.: Geophysical validation of MIPAS-ENVISAT operational ozone data, Atmos. Chem. Phys., 7, 4807-4867, doi:10.5194/acp-7-4807-2007, 2007.

Dee, D. P., Uppala, S. M., Simmons, A. J., Berrisford, P., Poli, P., Kobayashi, S., Andrae, U., Balmaseda, M. A., Balsamo, G., Bauer, P., Bechtold, P., Beljaars, A. C. M., van de Berg, L., Bidlot, J., Bormann, N., Delsol, C., Dragani, R., Fuentes, M., Geer, A. J., Haimberger, L., Healy, S. B., Hersbach, H., Holm, E. V., Isaksen, L., Kallberg, P., Kohler, M., Matricardi, M., McNally, A. P., Monge-Sanz, B. M., Morcrette, J. J., Park, B. K., Peubey, C., de Rosnay, P., Tavolato, C., Thepaut, J. N., and Vitart, F.: The ERA-Interim reanalysis: configuration and performance of the 
data assimilation system, Q. J. Roy. Meteorol. Soc., 137, 553597, doi:10.1002/qj.828, 2011.

Eldering, A., Kulawik, S. S., Worden, J., Bowman, K., and Osterman, G.: Implementation of cloud retrievals for TES atmospheric retrievals: 2. Characterization of cloud top pressure and effective optical depth retrievals, J. Geophys. Res.-Atmos., 113, D16S37, doi:10.1029/2007JD008858, 2008.

Fujiwara, M., Kita, K., and Ogawa, T.: Stratosphere-troposphere exchange of ozone associated with the equatorial Kelvin wave as observed with ozonesondes and rawinsondes, J. Geophys. Res.Atmos., 103, 19173-19182, doi:10.1029/98JD01419, 1998.

Hendon, H. H. and Salby, M. L.: The life-cycle of the MaddenJulian Oscillation, J. Atmos. Sci., 51, 2225-2237, 1994.

Huffman, G. J., Adler, R. F., Bolvin, D. T., Gu, G. J., Nelkin, E. J., Bowman, K. P., Hong, Y., Stocker, E. F., and Wolff, D. B.: The TRMM multisatellite precipitation analysis (TMPA): Quasiglobal, multiyear, combined-sensor precipitation estimates at fine scales, J. Hydrometeorol., 8, 38-55, doi:10.1175/jhm560.1, 2007.

Jourdain, L., Worden, H. M., Worden, J. R., Bowman, K., Li, Q., Eldering, A., Kulawik, S. S., Osterman, G., Boersma, K. F., Fisher, B., Rinsland, C. P., Beer, R., and Gunson, M.: Tropospheric vertical distribution of tropical Atlantic ozone observed by TES during the northern African biomass burning season, Geophys. Res. Lett., 34, L04810, doi:10.1029/2006GL028284, 2007.

Kyrola, E., Tamminen, J., Leppelmeier, G. W., Sofieva, V., Hassinen, S., Bertaux, J. L., Hauchecorne, A., Dalaudier, F., Cot, C., Korablev, O., D’Andon, O. F., Barrot, G., Mangin, A., Theodore, B., Guirlet, M., Etanchaud, F., Snoeij, P., Koopman, R., Saavedra, L., Fraisse, R., Fussen, D., and Vanhellemont, F.: GOMOS on Envisat: an overview, in: Climate Change Processes in the Stratosphere, Earth-Atmosphere-Ocean Systems, and Oceanographic Processes from Satellite Data, edited by: Schlussel, P., Stuhlmann, R., Campbell, J. W., and Erickson, C., Advances in Space Research, Pergamon-Elsevier Science Ltd, Kidlington, 1020-1028, 2004.

Kulawik, S. S., Worden, J., Eldering, A., Bowman, K., Gunson, M., Osterman, G. B., Zhang, L., Clough, S. A., Shephard, M. W., and Beer, R.: Implementation of cloud retrievals for Tropospheric Emission Spectrometer (TES) atmospheric retrievals: part 1. Description and characterization of errors on trace gas retrievals, J. Geophys. Res.-Atmos., 111, D24204, doi:10.1029/2005JD006733, 2006.

Lau, W. K. M. and Waliser, D. E.: Intraseasonal Variability in the Atmosphere-Ocean Climate System, Springer-Verlag, 436 pp., 2006.

Levelt, P. F., Hilsenrath, E., Leppelmeier, G. W., van den Oord, G. H. J., Bhartia, P. K., Tamminen, J., de Haan, J. F., and Veefkind, J. P.: Science objectives of the Ozone Monitoring Instrument, IEEE T. Geosci. Remote, 44, 1199-1208, doi:10.1109/TGRS.2006.872336, 2006a.

Levelt, P. F., van den Oord, G. H. J., Dobber, M. R., Mälkki, A., Visser, H., de Vries, J., Stammes, P., Lundell, J. O. V., and Saari, H.: The Ozone Monitoring Instrument, IEEE T. Geosci. Remote, 44, 1093-1101, doi:10.1109/TGRS.2006.872333, 2006b.

Li, K.-F., Tian, B., Waliser, D. E., and Yung, Y. L.: Tropical mid-tropospheric $\mathrm{CO}_{2}$ variability driven by the MaddenJulian oscillation, P. Nat. Acad. Sci. USA, 107, 19171-19175, doi:10.1073/pnas.1008222107, 2010.
Livesey, N. J., Read, W. G., Lambert, A., Cofield, R. E., Cuddy, D. T., Froidevaux, L., Fuller, R. A., Jarnot, R. F., Jiang, J. H., Jiang, Y. B., Knosp, B. W., Kovalenko, L. J., Pickett, H. M., Pumphrey, H. C., Santee, M. L., Schwartz, M. J., Stek, P. C., Wagner, P. A., Waters, J. W., and Wu., D. L.: EOS Aura MLS Version 2.2 Level 2 data quality and description document, Technical Report JPL D-33509, Jet Propulsion Laboratory, available online at: http: //mls.jpl.nasa.gov/data/v2-2_data_quality_document.pdf, 2007.

Livesey, N. J., Filipiak, M. J., Froidevaux, L., Read, W. G., Lambert, A., Santee, M. L., Jiang, J. H., Pumphrey, H. C., Waters, J. W., Cofield, R. E., Cuddy, D. T., Daffer, W. H., Drouin, B. J., Fuller, R. A., Jarnot, R. F., Jiang, Y. B., Knosp, B. W., Li, Q. B., Perun, V. S., Schwartz, M. J., Snyder, W. V., Stek, P. C., Thurstans, R. P., Wagner, P. A., Avery, M., Browell, E. V., Cammas, J. P., Christensen, L. E., Diskin, G. S., Gao, R. S., Jost, H. J., Loewenstein, M., Lopez, J. D., Nedelec, P., Osterman, G. B., Sachse, G. W., and Webster, C. R.: Validation of Aura Microwave Limb Sounder $\mathrm{O}_{3}$ and $\mathrm{CO}$ observations in the upper troposphere and lower stratosphere, J. Geophys. Res.-Atmos., 113, S15S02, doi:10.1029/2007JD008805, 2008.

Liu, C. X., Liu, Y., Cai, Z. N., Gao, S. T., Lu, D. R., and Kyrola, E.: A Madden-Julian Oscillation-triggered record ozone minimum over the Tibetan Plateau in December 2003 and its association with stratospheric "low-ozone pockets", Geophys. Res. Lett., 36, L15830, doi:10.1029/2009GL039025, 2009.

Liu, X., Bhartia, P. K., Chance, K., Froidevaux, L., Spurr, R. J. D., and Kurosu, T. P.: Validation of Ozone Monitoring Instrument (OMI) ozone profiles and stratospheric ozone columns with Microwave Limb Sounder (MLS) measurements, Atmos. Chem. Phys., 10, 2539-2549, doi:10.5194/acp-10-2539-2010, 2010a.

Liu, X., Bhartia, P. K., Chance, K., Spurr, R. J. D., and Kurosu, T. P.: Ozone profile retrievals from the Ozone Monitoring Instrument, Atmos. Chem. Phys., 10, 2521-2537, doi:10.5194/acp-10-25212010, 2010b.

Madden, R. A. and Julian, P. R.: Detection of a 40-50 Day Oscillation in Zonal Wind in Tropical Pacific, J. Atmos. Sci., 28, 702-708, 1971.

Madden, R. A. and Julian, P. R.: Description of global-scale circulation cells in tropics with a 40-50 day period, J. Atmos. Sci., 29, 1109-1123, 1972.

Rodgers, C. D.: Inverse Methods of Atmospheric Sounding: Theory and Practice, World Scientific Publishing Company, Singapore, 240 pp., 2000.

Stolarski, R. S. and Frith, S. M.: Search for evidence of trend slowdown in the long-term TOMS/SBUV total ozone data record: the importance of instrument drift uncertainty, Atmos. Chem. Phys., 6, 4057-4065, doi:10.5194/acp-6-4057-2006, 2006.

Schwartz, M. J., Lambert, A., Manney, G. L., Read, W. G., Livesey, N. J., Froidevaux, L., Ao, C. O., Bernath, P. F., Boone, C. D., Cofield, R. E., Daffer, W. H., Drouin, B. J., Fetzer, E. J., Fuller, R. A., Jarnot, R. F., Jiang, J. H., Jiang, Y. B., Knosp, B. W., Kruger, K., Li, J.-L. F., Mlynczak, M. G., Pawson, S., Russell, J. M., Santee, M. L., Snyder, W. V., Stek, P. C., Thurstans, R. P., Tompkins, A. M., Wagner, P. A., Walker, K. A., Waters, J. W., and $\mathrm{Wu}, \mathrm{D}$. L.: Validation of the Aura Microwave Limb Sounder Temperature and Geopotential Height Measurements, J. Geophys. Res., 113, D15S11, doi:10.1029/2007JD008783, 2008.

Thompson, A. M., Witte, J. C., Oltmans, S. J., and Schmidlin, F. J.: SHADOZ - A tropical ozonesonde-radiosonde network for 
the atmospheric community, B. Am. Meteorol. Soc., 85, 15491564, doi:10.1175/BAMS-85-10-1549, 2004.

Thompson, A. M., Witte, J. C., Smit, H. G. J., Oltmans, S. J., Johnson, B. J., Kirchhoff, V., and Schmidlin, F. J.: Southern Hemisphere Additional Ozonesondes (SHADOZ) 1998-2004 tropical ozone climatology: 3. Instrumentation, station-to-station variability, and evaluation with simulated flight profiles, J. Geophys. Res.-Atmos., 112, D03304, doi:10.1029/2005JD007042, 2007.

Tian, B. and D. E. Waliser: Chemical and biological impacts, Chapter 18, in: Intraseasonal Variability of the Atmosphere-Ocean System (2nd Edition), edited by: Lau, K.-M. and Waliser, D. E., Springer, Heidelberg, Germany, 2011.

Tian, B., Yung, Y. L., Waliser, D. E., Tyranowski, T., Kuai, L., Fetzer, E. J., and Irion, F. W.: Intraseasonal variations of the tropical total ozone and their connection to the Madden-Julian oscillation, Geophys. Res. Lett., 34, L08704, doi:10.1029/2007GL029451, 2007.

Tian, B., Waliser, D. E., Kahn, R. A., Li, Q., Yung, Y. L., Tyranowski, T., Geogdzhayev, I. V., Mishchenko, M. I., Torres, O., and Smirnov, A.: Does the Madden-Julian oscillation influence aerosol variability?, J. Geophys. Res.-Atmospheres, 113, D12215, doi:10.1029/2007JD009372, 2008.

Tian, B., Waliser, D. E., Fetzer, E. J., and Yung, Y. L.: Vertical Moist Thermodynamic Structure of the Madden-Julian Oscillation in Atmospheric Infrared Sounder Retrievals: An Update and a Comparison to ECMWF Interim Re-Analysis, Mon. Weather Rev., 138, 4576-4582, doi:10.1175/2010MWR3486.1, 2010.

Tian, B., Waliser, D. E., Kahn, R. A., and Wong, S.: Modulation of Atlantic aerosols by the Madden-Julian oscillation, J. Geophys. Res., 116, D15108, doi:10.1029/2010JD015201, 2011.

Waliser, D. E., Lau, K. M., Stern, W., and Jones, C.: Potential predictability of the Madden-Julian oscillation, B. Am. Meteorol. Soc., 84, 33-50, doi:10.1175/BAMS-84-1-33, 2003.

Waliser, D. E., Murtugudde, R., Strutton, P., and Li, J. L.: Subseasonal organization of ocean chlorophyll: Prospects for prediction based on the Madden-Julian Oscillation, Geophys. Res. Lett., 32, L23602, doi:10.1029/2005GL024300, 2005.

Waters, J. W., Froidevaux, L., Harwood, R. S., Jarnot, R. F., Pickett, H. M., Read, W. G., Siegel, P. H., Cofield, R. E., Filipiak, M. J., Flower, D. A., Holden, J. R., Lau, G. K. K., Livesey, N. J., Manney, G. L., Pumphrey, H. C., Santee, M. L., Wu, D. L., Cuddy, D. T., Lay, R. R., Loo, M. S., Perun, V. S., Schwartz, M. J., Stek, P. C., Thurstans, R. P., Boyles, M. A., Chandra, K. M., Chavez, M. C., Chen, G. S., Chudasama, B. V., Dodge, R., Fuller, R. A., Girard, M. A., Jiang, J. H., Jiang, Y. B., Knosp, B. W., LaBelle, R. C., Lam, J. C., Lee, K. A., Miller, D., Oswald, J. E., Patel, N. C., Pukala, D. M., Quintero, O., Scaff, D. M., Van Snyder, W., Tope, M. C., Wagner, P. A., and Walch, M. J.: The Earth Observing System Microwave Limb Sounder (EOS MLS) on the Aura satellite, IEEE T. Geosci. Remote, 44, 1075-1092, doi:10.1109/TGRS.2006.873771, 2006
Weare, B. C.: Madden-Julian Oscillation in the tropical stratosphere, J. Geophys. Res.-Atmos., 115, D17113, doi:10.1029/2009JD013748, 2010.

Wheeler, M. C. and Hendon, H. H.: An all-season real-time multivariate MJO index: Development of an index for monitoring and prediction, Mon. Weather Rev., 132, 1917-1932, 2004.

Wong, S. and Dessler, A. E.: Regulation of $\mathrm{H}_{2} \mathrm{O}$ and $\mathrm{CO}$ in tropical tropopause layer by the Madden-Julian oscillation, J. Geophys. Res.-Atmos., 112, D14305, 10.1029/2006JD007940, 2007.

Worden, J., Kulawik, S. S., Shephard, M. W., Clough, S. A., Worden, H., Bowman, K., and Goldman, A.: Predicted errors of tropospheric emission spectrometer nadir retrievals from spectral window selection, J. Geophys. Res.-Atmos., 109, D09308, doi:10.1029/2004JD004522, 2004.

Worden, H. M., Logan, J. A., Worden, J. R., Beer, R., Bowman, K., Clough, S. A., Eldering, A., Fisher, B. M., Gunson, M. R., Herman, R. L., Kulawik, S. S., Lampel, M. C., Luo, M., Megretskaia, I. A., Osterman, G. B., and Shephard, M. W.: Comparisons of Tropospheric Emission Spectrometer (TES) ozone profiles to ozonesondes: Methods and initial results, J. Geophys. Res.-Atmos., 112, D03309, doi:10.1029/2006JD007258, 2007.

Zhang, C.: Madden-Julian oscillation, Rev. Geophys., 43, RG2003, doi:10.1029/2004RG000158, 2005.

Zhang, C. and Dong, M.: Seasonality in the Madden-Julian oscillation, J. Clim., 17, 3169-3180, 2004.

Ziemke, J. R. and Chandra, S.: A Madden-Julian Oscillation in tropospheric ozone, Geophys. Res. Lett., 30, 2182, doi:10.1029/2003GL018523, 2003 